
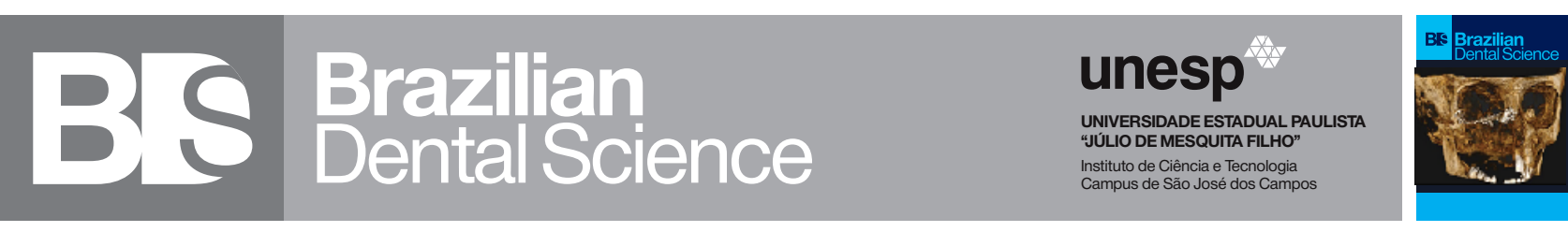

\title{
Effect of Different Immediate Implant Loading Protocols on Peri- implant Soft Tissue Health
}

\author{
Efeito de diferentes protocolos de implante com carga imediata no tecido mole peri-implantar
}

Ashraf REFAIE ${ }^{1}$, Maged ZOHDY ${ }^{2}$, Ahmad ABOELFADL ${ }^{2}$, Marwa WAHSH

1 - Fayoum University - Faculty of Dentistry - Department of Fixed Prosthodontics - Egypt.
2 - Ain Shams University - Faculty of Dentistry - Department of Fixed Prosthodontics - Egypt.

\section{ABSTRACT}

Objectives: This clinical study was conducted to evaluate the effect of immediate loading on periimplant soft tissue health using three protocols: I) Immediate functional loading using polymer infiltrated ceramic (PIC) material (IFLV). II) Immediate functional loading using polymethyl methacrylate (PMMA) followed by delayed functional loading using PIC material (IFLP). III) Immediate non-functional loading using PMMA followed by delayed functional loading using PIC material (INFLP). Material \& Methods: 30 Implants were placed in the upper premolar area and divided randomly according to the immediate loading protocol. In the control group (INFLP), CAD/ CAM PMMA crowns were placed out of occlusion for 3 months, and then replaced by CAD/CAM VITA ENAMIC crowns in functional occlusion. For (IFLV) group, CAD/ CAM VITA ENAMIC crowns were immediately loaded in functional occlusion; while in (IFLP) group, CAD/ CAM PMMA crowns were placed in functional occlusion for 3 months, and then replaced by CAD/CAM VITA ENAMIC crowns. Modified pink esthetic score (MPES) and probing depth were used for evaluation of periimplant soft tissue at base line and follow up periods. Results: INFLP showed higher MPES results compared to IFLV and IFLP. Moreover, the INFLP probing depth at 3 months showed higher results compared to the other groups. Conclusions: Immediate non-functional loading showed the best outcomes. However, peri-implant soft tissue health of the immediate functional loading using the PIC crown material was clinically acceptable.

\section{KEYWORDS}

Polymer infiltrated ceramics; Immediate dental implant loading; Peri-implant soft tissue health.

\section{RESUMO}

Objetivo: Este estudo clínico foi realizado para avaliar o efeito da carga imediata na saúde do tecido mole peri-implantar usando três protocolos: I) Carga imediata funcional usando material de cerâmica infiltrada com polímero (PIC) (IFLV). II) Carga imediata funcional usando polimetilmetacrilato (PMMA) seguida por carga funcional retardada usando material PIC (IFLP). III) Carga imediata não funcional usando PMMA seguida por carga funcional retardada usando material PIC (INFLP). Material e Métodos: 30 implantes foram colocados na área dos pré-molares superiores e divididos aleatoriamente de acordo com o protocolo de carga imediata. No grupo controle (INFLP), as coroas CAD / CAM PMMA foram colocadas sem oclusão por 3 meses, e então substituídas pelas coroas CAD / CAM VITA ENAMIC na oclusão funcional. Para o grupo (IFLV), as coroas CAD / CAM VITA ENAMIC foram carregadas imediatamente em oclusão funcional; enquanto no grupo (IFLP), as coroas CAD / CAM PMMA foram colocadas em oclusão funcional por 3 meses, e então substituídas por coroas CAD / CAM VITA ENAMIC. O escore da estética rosa modificado (PESM) e a profundidade de sondagem foram realizados para avaliação do tecido mole peri-implantar no início e nos períodos de acompanhamento. Resultados: INFLP apresentou resultados de PESM superiores em comparação com IFLV e IFLP. Além disso, a profundidade de sondagem INFLP em 3 meses apresentou resultados superiores em comparação com os outros grupos. Conclusões: A carga imediata não funcional apresentou os melhores resultados. No entanto, a integridade do tecido mole peri-implantar da carga imediata funcional usando o material da coroa PIC foi clinicamente aceitável.

\section{PALAVRAS-CHAVE}

Cerâmicas infiltradas com polímeros; Carregamento imediato do implante dentário; Saúde do tecido mole peri-implantar. 


\section{INTRODUCTION}

Tmplants are the first treatment option to 1 restore missing teeth. Their surfaces have been improved to enhance the Osseo-integration process [1]. The problem is no longer about osseointegration but the esthetic challenges [2].

Recession of the soft tissue margin may occur after the crown insertion, with the risk of having the titanium part of the implant unit exposed orally. Esthetic challenges may be related to the effect of occlusal forces on the implant, causing bone loss and soft tissue changes. It was suggested that loading protocols might be shortened through 2 different approaches. The first approach was the early loading of dental implant, where the implant is placed in function within 48 hours up to 3 months of implant placement. The second was the immediate loading protocols that can keep the amount of micromotion beneath the threshold of deleterious micromotion. It was found that successful premature loading protocols require a careful and strict patient selection aimed to achieve the best primary stability [3].

Immediate non-functional loading was proposed to avoid occlusal contact in both centric and lateral excursions, to reduce the early risk of mechanical overload caused by function or para - function occlusion [4]. While in immediate functional loading, the restorations are placed within 48 hours of implant placement in occlusal contact with the opposing teeth [5].

Micromotion affects the osseointegration leading to implant failure. If micromotion can be reduced or eliminated under immediate functional loading, theoretically, it should allow osseointegration [6].

Insertion torque is very important for primary stability and as a nonlinear, indirect indicator of micromovement of an implant in bone. Several clinicians encourage under preparation of the surgical site to promote adequate torque at the time of implant placement [7].
Natural teeth are surrounded by periodontal ligaments that absorb the masticatory forces while dental implants lack these resilient periodontal ligaments so the forces will be transmitted directly to the bone [8]. Using a resilient material for crown could help in decreasing load on implant in immediate loading. It has been suggested that restoring the implants immediately with a temporary resin restoration will provide more resiliency and shock absorbing properties than brittle ceramics, thereby reducing stresses to the implant and the surrounding bone to permit for osseointegration to occur [9]. The complications arise with the use of acrylic resin restorations such as resin fracture, esthetic defects, and resin wear so it should be replaced with a more durable, permanent material after successful osseointegration has occurred [10]. New CAD/ CAM polymer infiltrated ceramic materials are being developed to combine the beneficial properties of ceramics, such as color stability and durability, with the advantages of composite resins, such as low abrasiveness and improved flexural properties, giving the advantage of decreasing occlusal forces on implants [11].

In 2006, Glauser et al. [12], concluded that the soft tissue reaction of successfully integrated, immediately loaded implants was compared to that of conventionally loaded implants with regard to periodontal and morphologic aspect.

Consequently, the objectives of the present study were to evaluate the effect of immediate loading of implants on peri-implant soft tissue health using three protocols: I) Immediate functional implant loading using PIC material. II) Immediate functional implant loading using provisional material followed by delayed functional loading using PIC material. III) Immediate non-functional implant loading using provisional material followed by delayed functional loading using PIC material.

The null hypothesis was that no statistically significant difference would be found on the soft tissue health between different immediate loading protocols. 


\section{MATERIALS AND METHODS}

This studywas a double-blinded randomized clinical trial, approved by the ethics committee of the faculty of dentistry Ain Shams University (FDASU-RECID 021712). A total sample size of 30 implants were placed in upper premolar healed socket in patients' aging between 25 and 40 years. This study was performed during the period from January 2018 to October 2019.

Selective sampling was done among the patients who came to the outpatient clinic of fixed prosthodontics department, faculty of dentistry, Ain Shams University. Patients were selected according to inclusion and exclusion criteria; Inclusion criteria: cases with good oral hygiene, systemically healthy patients, missing upper premolar bounded by a natural tooth anteriorly and posteriorly, bone diameter of $7 \mathrm{~mm}$ or more, and bone quality of D2 or D3. while the exclusion criteria included patients with metabolic disorders, poor bone quality and quantity, deep bite, or smokers.

All patients received the same treatment protocol performed by the same team, composed of an implantologist, a prosthodontist and a laboratory technician.

CBCT was done to the patients for implant planning and surgical guide construction. The surgical guide was fabricated using the principle of stereolithography (SLA). The seating and stability of the surgical guide were checked inside the patient's mouth. Drilling was done through the surgical guide using flapless technique. Twopiece implants (Neo CMI implant, Neo Biotech implant, Korea) having a diameter of $3.5 \mathrm{~mm}$ and a height of 10 or $11.5 \mathrm{~mm}$, according to the bone height in the CBCT were inserted. Primary stability was checked with a $30 \mathrm{~N} / \mathrm{cm}$ torque wrench (Figure 1). The internal hex of the implant was irrigated, and the healing cap was screwed inside the implant using the hex driver. A post-operative CBCT was done to ensure the proper position of the implant within the bone.

On the same day of the surgery, single step impression with open tray technique was taken. The implant level replicas (laboratory analogues) were screwed into the impression copings with the hex driver. The soft tissue casts (gingival mimic) were poured to allow for proper emergence profile designing of the crowns. Then closed straight abutments, with internal hex prosthetic connection, were screwed over the implant analogues.

Occlusal reduction of the abutments was made to create $2 \mathrm{~mm}$ occlusal clearance to receive the restoration. Casts were scanned using an extra-oral scanner (Identica blue hybrid, MEDIT corp. Seoul, Korea). Designing of the crowns was done using Exocad 2016 software (Exocad $\mathrm{GmbH}$, Darmstadt, Germany). Designing tools were used to have proper emergence profile and to adjust occlusal surface according to group (Figure 2). An $80 \mu \mathrm{m}$ cement gap was created starting $1 \mathrm{~mm}$ above the margin.

The patients were divided randomly (using computer software) according to the immediate loading protocol into 3 groups (10 patients each):

Group (IFLV): patients received CAD/CAM VITA ENAMIC crown (VITA Zahnfabrik H. Rauter $\mathrm{GmbH}$ \& Co.KG Spitalgasse Germany) using immediate functional loading protocol, in which the occlusal parameters during the $\mathrm{CAD}$ procedure were adjusted to establish a light occlusal contact in centric occlusion. After the milling procedure, final adjustments of the crowns were performed inside the patient's mouth using a 200-micron articulating paper to remove any heavy contacts. An additional occlusal checking was performed with 40 micron articulating paper to ensure that a light occlusal marking was achieved on the implant restoration while heavy markings were achieved by the adjacent natural teeth.

Group (INFLP): patients received CAD/ CAM PMMA crowns (Vipi block, vipi,Brasil) out of occlusion for 3 months. The occlusal parameters during the $\mathrm{CAD}$ procedure were adjusted to have no occlusal contact in centric occlusion or lateral excursive movements. After the milling procedure, final adjustments of the crowns were performed inside the patient's mouth with articulating paper to ensure no contact in centric and eccentric movements. After 3 months, the crowns were 
replaced by CAD/CAM VITA ENAMIC crown in functional occlusion.

Group (IFLP): patients received CAD/ CAM PMMA crowns in functional occlusion, the occlusion was checked in the same manner as IFLV group. After 3 months they were replaced by CAD/CAM VITA ENAMIC crown in functional occlusion.

The crowns were placed over their corresponding abutments and checked for contact, occlusion and shade (Figures 3 and 4). All crowns were cemented using a temporary cement (Dento temp, Itena clinical products, France), excess cement was removed using a round blade sickle scaler (Hu-Friedy, Chicago, USA), and dental floss for interproximal area.

All follow up assessments were done by two well trained blinded observers different from the implant surgeon and prosthodontist; Before the start of the study, they were well trained to adequate levels of accuracy and reproducibility for the various measurements and indices to be used. They were blinded regarding the patient's group to avoid any bias. All assessments were done by directly assessing the patients. The neighboring teeth were used as references for comparison. The mean of the observers' scores was recorded.

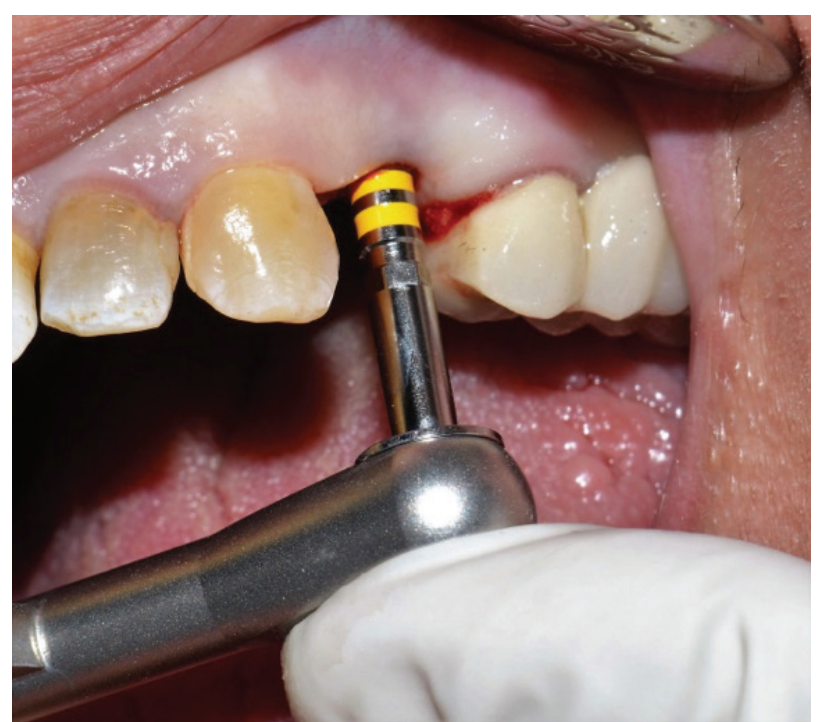

Figure 1 - Checking implant primary stability with torque wrench.

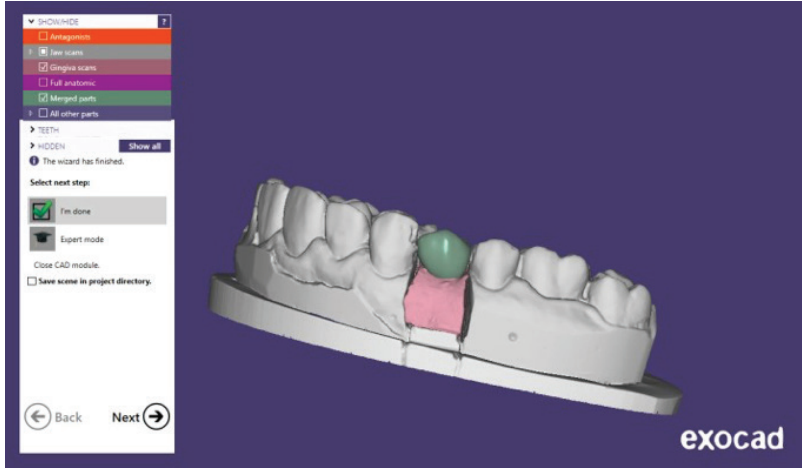

Figure 2 - Digital designing of the restoration with soft tissue simulation.

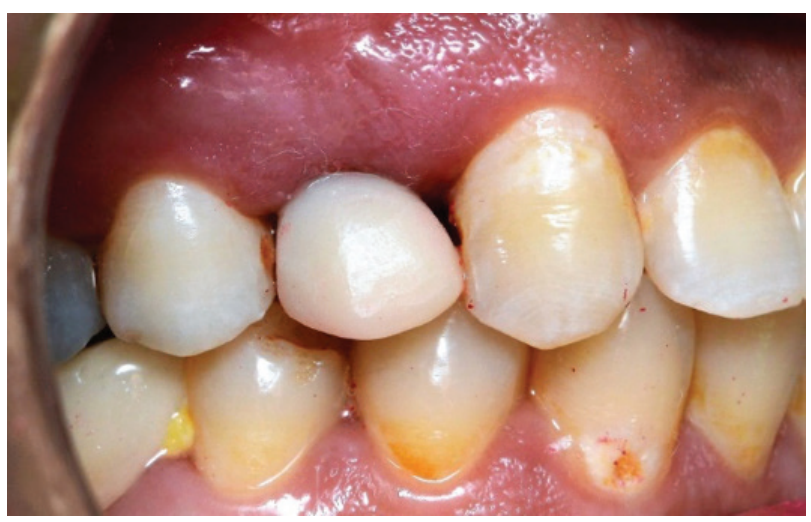

Figure 3 - Delivery of PMMA crown.

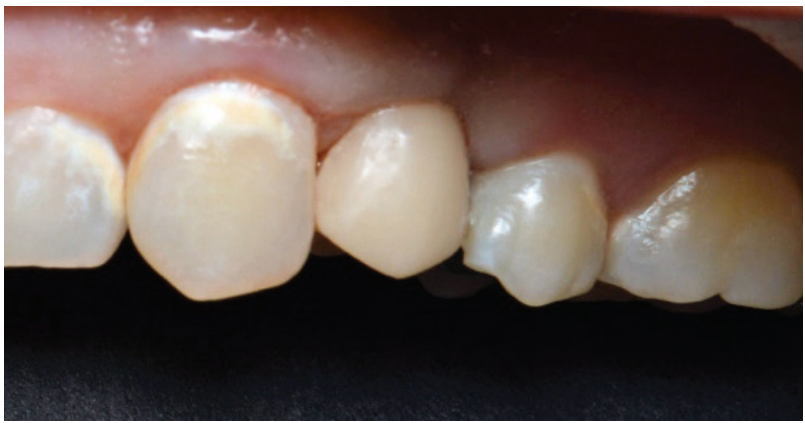

Figure 4 - Delivery of VITA-ENAMIC crown.

\section{Method of evaluation}

Patients were evaluated for soft tissue health at the time of crown cementation, and reexamination was scheduled 3, 6 and 12-months intervals postoperatively. Evaluation was based on the assessment of peri-implant soft tissue by means of modified pink esthetic score (MPES) and periodontal pocket depth. 
The modified pink esthetic score comprises the following five variables: mesial papilla, distal papilla, curvature of the facial mucosa, level of the facial mucosa, and root convexity/soft tissue color and texture at the facial aspect of the implant site. A score of 2, 1, or 0 was assigned to all five MPES parameters; The five described parameters were added. Under optimum conditions, the score will be 10; the threshold of clinical acceptability was set at 6 .

The results were presented as mean and standard deviation (SD). Kruskal Wallis test was used to compare between different test groups for non-parametric data. Wilcoxon signed-rank test was used to compare between follow-up periods.

Repeated measure ANOVA was used to compare between the test groups and follow-up periods followed by pairwise comparison with Bonferroni correction. The significance level was set at $\mathrm{P} \leq 0.05$. Statistical analysis was performed with IBM ${ }^{\circledR}$ SPSS ${ }^{\circledR}$ (SPSS Inc., IBM Corporation, NY, USA) Statistics Version 25 for Windows.

\section{RESULTS}

\section{Modified pink esthetic score (MPES)}

The results of INFLP group showed higher results compared to other groups at follow up periods 3,6 and 12 months.

For IFLV group, there was no significant difference between baseline and 3 months; and no significant difference between 6 months and 12 months. Moreover, baseline and 3 months showed higher results compared to 6 months and 12 months.

For IFLP group, there was significant difference between baseline and 3 months follow up but there was no significant difference between 3, 6 and 12 months follow up.

For INFLP group, the results at 6 months follow up period were higher than the baseline. There was no significant difference between baseline, 3 months and 12 months. Moreover, there was no significant difference between the follow up periods. (table 1)
Table I - Mean and Standard deviation (SD) values for MPES of different groups and follow-up intervals.

\begin{tabular}{|c|c|c|c|}
\hline \multirow{2}{*}{ Follow-up } & \multicolumn{3}{|c|}{ Modified pink esthetic score (Mean \pm SD) } \\
\hline & (IFLV) & (IFLP) & (INFLP) \\
\hline Baseline & $8.10 \pm 0.57^{\text {Аа }}$ & $8.30 \pm 0.48^{\text {Аа }}$ & $8.70 \pm 0.48^{\mathrm{Ab}}$ \\
\hline 3 months & $8.10 \pm 0.57^{\mathrm{Ba}}$ & $7.70 \pm 0.48^{\mathrm{Bb}}$ & $9.10 \pm 0.57^{\text {Aab }}$ \\
\hline 6 months & $7.70 \pm 0.82^{\mathrm{Bb}}$ & $7.60 \pm 0.70^{\mathrm{Bb}}$ & $9.50 \pm 0.71^{\text {Aa }}$ \\
\hline 12 months & $7.40 \pm 0.70^{\mathrm{Bb}}$ & $7.50 \pm 0.85^{\mathrm{Bb}}$ & $9.20 \pm 0.79^{\text {Aab }}$ \\
\hline
\end{tabular}

Different upper and lowercase superscript letters indicate statistically significant difference within the same horizontal row and vertical column respectively.

\section{Probing depth}

At 3 months follow up period, INFLP group showed lower probing depth results than the other 2 groups. However, there was no significant difference between all groups at baseline, 6 months and 12 months.

For all groups, the probing depths results at 3 months were lower than 6 and 12 months. (table 2).

Table 2 - Mean and Standard deviation (SD) values for probing depth $(\mathrm{mm})$ of different groups and follow-up intervals.

\begin{tabular}{|cccc|}
\hline Follow-up & \multicolumn{3}{c|}{ Probing depth (Mean \pm SD) } \\
\hline Baseline & (IFLV) & (IFLP) & (INFLP) \\
\hline 3 months & $2.70 \pm 0.48^{\mathrm{Ab}}$ & $1.60 \pm 0.57^{\mathrm{Ab}}$ & $1.60 \pm 0.64^{\mathrm{Aab}}$ \\
\hline 6 months & $2.55 \pm 0.53^{\mathrm{Aa}}$ & $1.85 \pm 0.34 \mathrm{~A}^{\mathrm{Bb}}$ & $1.50 \pm 0.47^{\mathrm{Bb}}$ \\
\hline 12 months & $2.55 \pm 0.55^{\mathrm{Aa}}$ & $2.10 \pm 0.52^{\mathrm{Aa}}$ \\
\hline
\end{tabular}

Different upper and lowercase superscript letters indicate a statistically significant difference within the same horizontal row and vertical column respectively.

\section{DISCUSSION}

Dental patients have become more demanding, requesting shorter treatment periods and less surgical procedures. Thus, immediate loading of dental implants has become more common in the past couple of decades. An understanding of proper patient selection for the immediate loading procedure has greatly increased the overall success rates of immediate loading to the point that the results are comparable to conventional loading protocols [3]. 
The null hypothesis of the study was rejected. In the current study, no implants were lost in all groups. The MPES of all groups were within the acceptable range of all biological and esthetic outcomes, where the threshold of clinical acceptability is above the score 6 , as stated by Besler et al. [13] This could be related to the conservative surgical approach, in agreement with Patil et al. [14] This was also in agreement with Bahammam et al., [15] who found that immediate loading of dental implant had better effect on the oral health-related quality of life.

Moreover, the MPES results of the INFLP were significantly higher than IFLP and IFLV, in agreement with Ramachandran et al. (2016) [16] who conducted a study to assess the alveolar bone density around immediate functional and immediate non - functional loading, they found that the excessive loading of immediate functional loading resulted in a significantly larger amount of bone demineralization at the alveolar crest compared to immediate non functional loading. Also Charcanovic et al. [6] concluded that the immediate functional loading of implants resulted in a significantly higher bone demineralization from implant placement up to 3 months compared with immediate nonfunctional loading which might be due to the micro-motion of immediate functionally loaded implants.

It's worth mentioning that soft tissue level is highly directly related to bone demineralization where the loss of peri-implant marginal bone could affect the peri-implant mucosa and hence the esthetic outcome [17]. The soft tissue changes are an early sign for detection of peri-implant diseases before progression of the disease which can eventually lead to severe bone loss and implant failure [18].

On the contrary Degidi et al. [19] found no significant difference in survival rate and soft tissue healing pattern between functional and non-functional immediate loading of implants, this may be attributed to the immediate splinting used in their study.

In INFLP, the scores were improved at 3 and 6 months follow up intervals; this may be attributed to non-functional occlusion at the first 3 months and replacing the temporary PMMA with VITA ENAMIC that has a glazed surface and is more biocompatible [20]. However, in IFLP group, the results at 3 months interval results were lower than baseline, this may be due to immediate loading, subjecting the implant to occlusal forces, leading to higher bone demineralization in the first 3 month, as stated by Charcanovic et al. [6].

The results of probing depth showed no significant difference, and all were within the acceptable clinical findings. Studies have indicated that successful implants allow probe penetration not exceeding $3 \mathrm{~mm}$ [21].

Concerning the probing depth in tested groups, significant difference between INFLP and the other 2 groups in 3 months follow up interval was noticed, this may be due to non-functional occlusion on implants in INFLP group. Within each group, a statistically significant increase in probing depth was observed within follow up intervals which may be due to functional occlusion. This observation might need a longer follow-up period to assess whether the increase in pocket depth by time will continue or whether it will stabilize. Previous studies have shown a stable peri-implant probing depth after 3 years [22].

Limited number of patients, accurate observation of patient inclusion/exclusion criteria, conservative surgical technique, strict periodontal and prosthetic monitoring and short observation period, could be some limitation for a short-term study.

\section{CONCLUSION}

Within the limitations of this study, the following conclusions could be drawn:

1. Immediate non-functional loading showed the most predictable soft tissue health among all test periods;

2. Immediate functional loading using the polymer infiltrated ceramic crown material showed clinical acceptable peri-implant soft tissue health; 
3. All peri-implant esthetic and biological outcomes were within the acceptable range and remained relatively stable throughout the twelve months follow up period of the study.

\section{REFERENCES}

1. Cooper KG. Rapid prototyping technology: selection and application. New York: Marcel Dekker;2001.

2. Nociti FH Jr, Cesco De Toledo R,Machado MA, Stefani CM, Line SR, Gonçalves RB. Clinical and microbiological evaluation of ligature-induced peri-implantitis and periodontitis in dogs. Clin Oral Implants Res. 2001;12(4):295-300. doi:10.1034/.1600-0501.2001.012004295.x.

3. Szmukler-Moncler S, Piattelli A, Favero GA, Dubruille JH. Considerations preliminary to the application of early and immediate loading protocols in dental implantology. Clin Oral Implants Res. 2000;11(1):12-25. doi:10.1034/j.16000501.2000.011001012.x.

4. Misch CE Nonfunctional immediate teeth. Dent Today. 1998;17(6):88-91.

5. Degidi M, Piattelli A. Immediate functional and non-functional loading of dental implants: a 2-to 60-month follow-up study of 646 titanium implants. J Periodontol. 2003;74(2):225-41. doi:10.1902/jop.2003.74.2.225.

6. Chrcanovic BR, Albrektsson T, Wennerberg A. Immediate nonfunctional versus immediate functional loading and dental implant failure rates: a systematic review and meta-analysis. J Dent. 2014;42(9):1052-9. doi:10:1016/j. jdent.2014.06.010.

7. Chung S, McCullagh A, Irinakis T. Immediate loading in the maxillary arch: evidence-based guidelines to improve success rates: a review. J Oral Implantol 2011;37(5):610-21. doi:10.1563/AAID-D-JOI-10-00058.1.

8. Magne P,Silva M, OderichE, Boff LL, Enciso R. Damping behavior of implant-supported restorations. Clin Oral Implants Res. 2013;24(2):143-8. doi:10.1111/j.1600-0501.2011.02311.x.

9. Ciftci Y,Canay S. The effect of veneering materials on stress distribution in implant-supported fixed prosthetic restorations. Int J Oral Maxillofac Implants. 2000;15(4):571-82

10. Carlson B,Carlsson GE. Prosthodontic complications in osseointegrated dental implant treatment. Int J Oral Maxillofac Implants. 1994;9(1):90-94.

11. Coldea A, Swain MV, Thiel N. Mechanical properties of polymer-infiltratedceramic-network materials. Dent Mater. 2013;29(4):419-26. doi:10.1016/j. dental.2013.01.002
12. Glauser R,Zembic A, HämmerleCH. A systematic review of marginal soft tissue at implants subjected to immediate loading or immediate restoration. Clin Oral Implants Res. 2006;17 Suppl 2:82-92. doi:10.1111//.16000501.2006.01355.x.

13. Belser UC, Grütter L, VailatiF, Bornstein MM, Weber HP,Buser D. Outcome evaluation of early placed maxillary anterior single-tooth implants using objective esthetic criteria: a cross-sectional, retrospective study in 45 patients with a 2- to 4-year follow-up using pink and white esthetic scores. J Periodontol.2009;80(1):140-51. doi:10.1902/jop.2009.080435.

14. Patil R, Gresnigt MMM, Mahesh K, Dilbaghi A, Cune MS. Esthetic evaluation of anterior single-tooth implants with different abutment designspatients' satisfaction compared to dentists' observations. J Prosthodont. 2017;26(5):395-8. doi:10.1111/jopr.12423.

15. Bahammam MA, Fareed WM. Effect of immediate versus delayed loadings of dental implants on the oral health-related quality of life in Saudi population. Experimental clinical trial. Saudi Med J. 2019;40(1):79-86. doi:10.15537/ smi.2019.1.23370

16. Ramachandran A, Singh K, Rao J, Mishra N, Jurel SK, Agrawal K. Changes in alveolar bone density around immediate functionally and non functionally loaded implants.JProsthet Dent 2016 Jun;115(6):712-7. doi: 10.1016/j. prosdent.2015.11.

17. Edward J,George JM, Prakash DG. Evaluation of peri-implant soft tissues and hard tissues in titanium implants in immediate and delayed cases: a comparative study.J DentImplants.2017;7(1)3-10. doi:10.4103/jdi.jdi_117.

18. Lang NP,Berglundh T, Heitz-Mayfield LJ, Pjetursson BE, Salvi GE, Sanz M. Consensus statements and recommended clinical procedures regarding implant survival and complications. Int J Oral Maxillofac Implants. 2004;19 Suppl:150-4.

19. Degidi M, Nardi D, Piattelli A. A comparison between immediate loading and immediate restoration in cases of partial posterior mandibular edentulism: a3-year randomized clinical trial. Clin Oral Implants Res. 2010;21(7):682-7. doi:10.1111/j.1600-0501.2009.01910.x

20. Kim KH, Loch C, Waddell JN, Tompkins G, Schwass D. Surface characteristics and biofilm development on selected dental ceramic materials. Int JDent 2017:2017:7627945. doi:10.1155/2017/7627945.

21. Guidetti LG, Monnazzi MS, Piveta AC, Gabrielli MA, Gabrielli MF,Pereira Filho VA. Evaluation of single implants placed in the posterior mandibular area under immediate loading: a prospective study. Int J Oral Maxillofac Surg. 2015;44(11):1411-5. doi:10.1016/.j.jom.2015.06.021.

22. Nemli SK, Güngör MB, AydınC, YlımazH, Bal BT,Aricı YK. Clinical and radiographic evaluation of new dental implant system: Results of a 3-year prospective study.JDent Sci. 2016;11(1):29-34. doi:10.1016/j.jds.2014.11.003.

\section{Ashraf Refaie \\ (Corresponding address)}

Faculty of dentistry, Fayoum university, teb al bahary, Fayoum, Egypt. (corresponding address ) I-smile dental center, 25 ahmed tayseer street, Ard al golf, Misr al gadida, Cairo, Egypt. 